\title{
REDESAIN LOGO DAN MEDIA PROMOSI SEBAGAI CITRA PRODUK MAKANAN RINGAN UKM BENOK
}

\author{
Faza Wahmuda ${ }^{1}$, Moch Junaidi Hidayat ${ }^{2}$ \\ 1,2 Jurusan Desain Produk, Fakultas Teknik Sipil dan Perencanaan, ITATS, Surabaya \\ faza.despro@itats.ac.id ${ }^{1}$, junaidi.despro@itats.ac.id²
}

\begin{abstract}
Abstrak
Perkembangan industri di Indonesia memberikan perubahan bagi Usaha Kecil Menengah (UKM) untuk bersaing memenuhi kebutuhan konsumen. Obyek penelitian ini pada UKM Benok di Desa Klampok Kecamatan Tongas Kabupaten Probolinggo hasil budi daya jagung yang diolah menjadi makanan ringan Emping dan Tortilla Jagung. UKM Benok memiliki peluang masuk di pasar swalayan. Namun identitas UKM Benok masih belum jelas dalam penerapan visualnya. Sehingga perlu meredesain logo Benok yang memiliki kekuatan identitas citra produk jagung. Upaya redesain dan media promosi dalam meningkatkan daya beli masyarakat adalah bagian dari proses mengungkap problematika yang dihadapi oleh UKM Benok, terutama bertujuan peningkatan citra produk makanan ringan. Melalui metode penelitian Desain proses pengumpulan data yang kemudian di lakukan analisis SWOT, analisis visual dan verbal guna menghasilkan redesain logo, analisis warna dan konfigurasi yang dijadikan dasar dalam mendesain label kemasan dan media promosi sebagai citra produk. Hasil penelitian ini yaitu pengembangan kemasan menggunakan standup pouch, mampu memberikan kemudahan konsumen dan meningkatkan kualitas produk Benok. Sedangkan penguatan citra produk dengan meredesain yang meliputi logo, naming dan warna serta pendekatan fotografi dalam penguatan visual pada desain label kemasan dan desain poster sebagai penguatan merek yang mampu bersaing di pasar dan mampu meningkatkan daya saing dari Benok.
\end{abstract}

Kata Kunci: citra produk, kemasan, logo, media promosi, redesain

\begin{abstract}
The development of industry in Indonesia provides a change for Small and Medium Enterprises (SMEs) or "Usaha Kecil Menengah (UKM)" to compete with consumers. The object of this research is Benok UKM in Klampok Village, Tongas Subdistrict, Probolinggo District, the results of corn cultivation processed were snacks, Emping, and Corn Tortillas. Benok UKM has the opportunity to enter the supermarket. However, the identity of Benok UKM is still unclear in its visual application. So it is necessary to redesign the Benok logo that has the strength of the corn product image identity. Efforts to redesign and promote media in increasing people's purchasing power are part of the process of uncovering the problems faced by Benok UKM by particularly aiming at improving the image of snack products. Through research design methods the process of collecting data is then carried out a SWOT analysis, visual and verbal analysis to produce logo redesign, color analysis, and configuration that are the basis for designing packaging labels and promotional media as product images. The results of this study are the development of packaging using standup pouch, able to provide consumer convenience, and improve the quality of Benok products. While strengthening the product image by redesigning that includes logos, naming, and colors as well as a photographic approach in visual reinforcement on the packaging label design and poster design as a reinforcement of a brand that can compete in the market and can increase the competitiveness of Benok.
\end{abstract}

Keywords: logo, packaging, product image, promotion media, redesign 


\section{PENDAHULUAN}

Perkembangan industri di Indonesia yang selalu meningkat di setiap tahunnya, memberikan dampak perubahan yang signifikan bagi para Usaha Kecil Menengah (UKM) untuk berlomba dan bersaing memenuhi kebutuhan konsumen masyarakat. Sebagaimana dalam kutipan laporan Opus Creative Economy Outlook 2019, ekonomi kreatif yang menjadi fokus pemerintah Indonesia ini terus tumbuh dengan pesat selama kurun waktu lima tahun terakhir. Badan Pusat Statistik (BPS) mencatat, Ekonomi Kreatif (Ekraf) berkontribusi sebesar 922 triliun, atau sekitar 7,44\% terhadap perekonomian nasional di tahun 2016. Hingga tahun 2019, angka ini diperkirakan terus tumbuh signifikan. Produk Domestik Bruto (PDB) Ekraf diperkirakan sudah mencapai lebih dari seribu triliun rupiah. Angka ini akan terus meningkat hingga di atas 1,2 ribu triliun pada 2019. Sub-sektor fesyen, kriya, dan kuliner masih akan menjadi sub-sektor yang memberikan kontribusi terbesar terhadap perekonomian di industri kreatif, terutama dikarenakan sub-sektor ini relatif lebih resisten terhadap guncangan ekonomi dunia. (OPUS, 2020)

Selain itu didukung dari hasil kesimpulan artikel dengan judul "Evaluasi Nilai Ekonomi Usaha Budi Daya Tanaman Jagung sebagai Tanaman Pakan dan Pangan di Kota Probolinggo" dikatakan bahwa usaha budi daya jagung sebagai tanaman pangan lebih menguntungkan dengan tingkat keuntungan Rp. 11.777.553,00 dan nilai B/C ratio sebesar 0,9 dibandingkan dengan sebagai tanaman pakan dengan keuntungan Rp. $6.345 .556,00$ dan nilai B/C ratio 0,7. Titik BEP usaha budi daya jagung di Kota Probolinggo didapatkan pada umur 40-50 hari. (Sulistya et al., 2018)

Penelitian ini dilakukan di Desa Klampok Kecamatan Tongas Kabupaten Probolinggo yang membangun budi daya tanaman jagung yang diolah menjadi aneka makanan ringan berupa Emping Jagung dan juga Tortilla Jagung. UKM (Usaha Kecil Menengah) ini dikelola oleh Ibu Winarti dengan pekerja berjumlah lima orang. Dukungan dari pemerintah daerah dan juga perangkat desa serta para Petani Jagung memberikan dampak yang signifikan bagi pelaku UKM Benok yang dimulai sejak tahun 2003. Perkembangan UKM Emping Jagung hingga di tahun 2015 cukup pesat, dikarenakan permintaan pasar yang cukup meningkat. Dalam perkembangannya di tahun 2018, UKM Benok mengalami penurunan, dalam satu minggu rata-rata hanya dapat terjual 15 buah saja. Penurunan ini diakibatkan produk UKM Benok belum mampu menembus pasar, keterbatasan media dalam pengenalan produk mereka disebabkan akses daerah yang masih belum terjangkau. Selain itu berdasarkan hasil wawancara dengan Ibu Winarti selaku pengelola UKM, Emping Jagung dan Tortila Jagung miliknya belum banyak dikenal masyarakat. Kualitas kemasan yang digunakan juga masih rendah sehingga kerenyahan Emping Jagung dan Tortila Jagung tidak tahan lama.

Disisi lain, manajemen pemasaran dan penyajian produk yang masih menjadi titik kelemahan produk ini. Hal ini disebabkan lingkup pemasaran yang dilakukan masih terbatas. Emping Jagung masih didistribusikan melalui perorangan dan hanya menjangkau di area Kota Pasuruan, Malang dan Surabaya. Sehingga perlu dilakukan strategi pemasaran yang lebih baik dan efektif. Emping Jagung memiliki peluang masuk 
di pasar swalayan baik minimarket ataupun Gerai Oleh - Oleh khas Probolinggo yang ada di Rest Area Tongas Probolinggo. Namun, perlu kaidah-kaidah penyajian produk yang baik. Bentuk kemasan produk Emping dan Tortilla Jagung seperti gambar 1 di bawah ini.
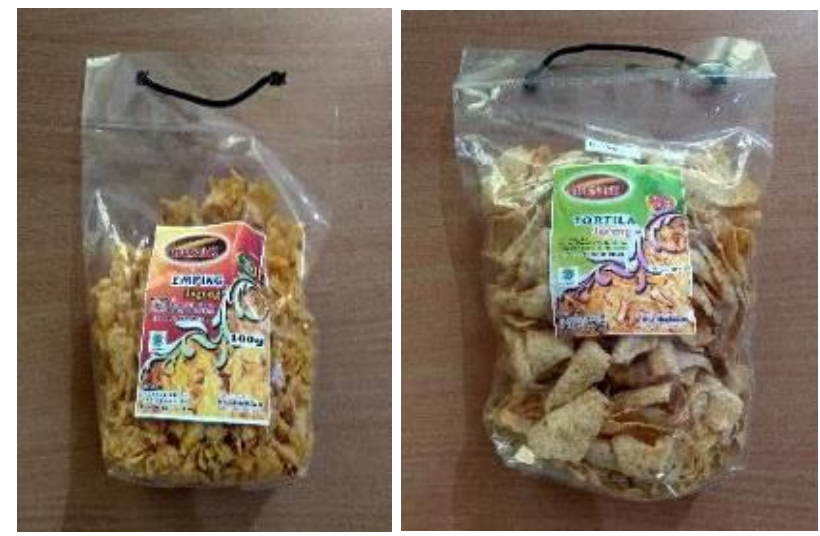

Gambar 1. Kemasan Produk Emping dan Tortila Jagung. [Sumber: Dokumentasi Penulis, 2018]

Pengembangan desain kemasan Emping Jagung yang saat ini perlu diredesain mengingat pemasaran Emping Jagung Benok memiliki peluang masuk di pasar swalayan oleh-oleh khas Probolinggo. (Wahmuda \& Hidayat, 2018).

Logo merupakan elemen desain sangat penting dan menjadi identitas visual. Penerapan logo selalu ada dalam aplikasi identitas visual lainnya. Oleh karena itu penting untuk merencanakan logo yang dapat mencerminkan kepribadian dan jiwa sebuah brand. (Oscario, 2013). Identitas logo UKM Benok masih belum memperlihatkan kualitas produk dengan segmen pasar yang lebih tinggi. UKM Benok memiliki logo seperti gambar 2 di bawah ini :

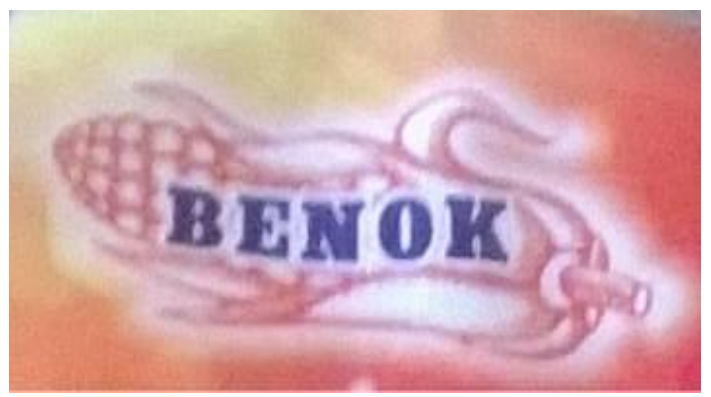

Gambar 2. Logo BENOK

[Sumber: Dokumentasi Penulis, 2018]

Logo benok di atas secara visual menunjukkan jagung sebagai identitasnya, hal ini bertujuan untuk memberikan pemahaman kepada konsumen bahwa produk emping dan tortilla tersebut berbahan jagung. Namun identitas visual jagung masih belum maksimal dalam penerapan logo, khususnya penerapan visual logo dengan skala kecil belum menunjukkan identitas secara jelas. Sehingga peneliti perlu meredesain logo Benok yang memiliki kekuatan identitas dan citra produk emping dan tortilla jagung. 
Tujuan penelitian ini adalah menganalisis dan merancang identitas visual dan media promosi UKM Benok yang sesuai dengan segmentasi pasar dan memperkuat citra identitas produk yang berkualitas.

\section{METODE PENELITIAN}

Melalui metode penelitian Desain dengan mengambil studi kasus UKM Benok sebagai produk makanan ringan daerah. Menurut Supardi, 2006:88 dalam Darmawan \& Swasty, 2018, obervasi adalah metode pengumpulan data yang dilakukan dengan mengamati dan juga mencatat secara sistematik. Proses pengumpulan data menggunakan metode observasi, studi pustaka, dan wawancara. Sedangkan objek yang didapat adalah data lapangan dari hasil observasi peneliti pada UKM Benok dalam dua tahun ini. Peneliti terlibat secara langsung membantu dalam proses desain melalui pelatihan maupun langsung terlibat dalam praktik secara langsung dalam strategi promosi produk olahan Emping Jagung menjadi produk unggulan daerah.

Hasil pengumpulan data ini kemudian di lakukan analisis faktor lingkungan internal dan eksternal yang kemudian dapat dirumuskan kekuatan, kelemahan, peluang dan ancaman (SWOT). Langkah berikutnya dilakukan analisis visual melalui analisis verbal guna menghasilkan redesain logo dan verbal yang kemudian dilakukan analisis warna, grid dan konfigurasi yang dijadikan dasar dalam membuat desain kemasan dan poster guna menyelesaikan persoalan penelitian desain di lapangan.

\section{HASIL DAN PEMBAHASAN}

UKM Benok adalah UKM yang bergerak dibidang makanan ringan Emping Jagung dan tortilla jagung. Produk tersebut merupakan hasil komoditas daerah yaitu petani jagung. Hasil pengumpulan data yang telah dilakukan terdapat beberapa faktor yang menjadi kendala pada UKM Benok. Faktor internal didapatkan dari hasil wawancara dan observasi terhadap satu pemilik dan lima pekerja UKM Benok dan 10 konsumen UKM Benok. Kualitas produk yang dihasilkan cukup diminati konsumen. Rasa yang dihasilkan memiliki kerenyahan yang berbeda dari produk lainnya. Sedangkan untuk perkembangan pemasaran masih belum menunjukkan peningkatan yang lebih cepat. Dari hasil wawancara dengan pemiliki UKM Benok, identitas produk belum menjadi keseriusan dalam produk ini. Hanya cukup memiliki nama saja. Sedangkan pentingnya citra produk menurut Schiffman \& Kanuk (2000) dalam (Ali et al., 2013) menyebutkan citra merek yang berbeda dan unik merupakan hal yang paling penting, karena produk semakin kompleks dan pasar semakin penuh, sehingga konsumen akan semakin bergantung pada citra merek daripada atribut merek yang sebenarnya untuk mengambil keputusan pembelian.

Selain itu, kemasan yang digunakan belum dapat memenuhi persyaratan untuk masuk di pasar swalayan. Perlu adanya pengembangan desain kemasan. Penemuan baru maupun pendesainan ulang penting bagi dinamika konsumerisme, keduanya menciptakan kebutuhan baru, hasrat baru, ketidakpuasan dengan sesuatu yang sudah ada melalui mekanisme keusangan psikologis. (Hidayat, 2011). Sedangkan menurut Klimchuk dan Krasovec (2007) dalam (Rosandi, 2014) mendefinisikan bahwa "Desain 
kemasan adalah bisnis kreaftif yang mengaitkan bentuk, struktural, material warna, citra, tipografi, dan elemen-elemen desain dengan informasi produk agar produk dapat dapat dipasarkan dan berlaku untuk pembungkus, melindungi, mengirim, mengeluarkan, menyimpan, dan membedakan sebuah produk yang pada akhirnya dapat mengkomunikasikan kepribadian atau fungsi produk konsumsi secara unik" .

Faktor eksternal dipengaruhi kebijakan pemerintah Kementerian bidang perekonomian untuk mendorong UMKM untuk naik kelas yaitu dengan Rancangan Undang-Undang Cipta Kerja. Tujuannya untuk memperluas peluang usaha demi pertumbuhan ekonomi yang berkualitas melalui kemudahan dan simplikasi perizinan, pemberdayaan usaha menengah, kecil, dan mikro (UMKM) dan koperasi, serta penciptaan lapangan kerja dan kesejahteraan pekerja yang berkelanjutan. (Kementerian Koordinator Bidang Perekonomian Republik Indonesia, n.d.). Dari analisis internal dan eksternal dapat dirumuskan dalam analisis SWOT pada tabel 1 di bawah ini.

Tabel 1. Strategi SWOT

[Sumber: Dokumentasi Penulis, 2018]

\begin{tabular}{|c|c|}
\hline Kekuatan & Kelemahan \\
\hline $\begin{array}{l}\text { 1. UKM Benok memiliki ketersediaan bahan } \\
\text { baku pangan yang melimpah. } \\
\text { 2. Memiliki citra rasa yang khas dan renyah. } \\
\text { 3. Telah memiliki ljin Usaha. } \\
\text { 4. Memiliki pelanggan konsumen yang } \\
\text { berkelanjutan. } \\
\text { 5. UKM Benok merupakan salah satu } \\
\text { kelompok wanita tani di Desa Klampok } \\
\text { sehingga masyarakat memiliki } \\
\text { pengalaman di bidang produk olahan } \\
\text { makanan ringan. }\end{array}$ & $\begin{array}{l}\text { 1. UKM Benok belum memiliki identitas } \\
\text { yang menjadi penciri produk. } \\
\text { 2. Pemasaran yang dilakukan hanya } \\
\text { secara offline dan menerima hanya } \\
\text { sesuai pesanan saja. } \\
\text { 3. Produk yang dihasilkan adalah } \\
\text { Emping Jagung yang kurang menarik } \\
\text { dari segi kemasan produk. } \\
\text { 4. Belum dapat masuk pasar swalayan } \\
\text { dikarenakan persyaratan kemasan } \\
\text { belum memenuhi. }\end{array}$ \\
\hline Peluang & Ancaman \\
\hline $\begin{array}{l}\text { 1. Pemerintah Kementerian bidang } \\
\text { perekonomian mendorong UMKM untuk } \\
\text { naik kelas. } \\
\text { 2. Pola hidup masyarakat saat ini yang lebih } \\
\text { modern. } \\
\text { 3. Makin banyak pasar swalayan di setiap } \\
\text { daerah. } \\
\text { 4. Makin banyak pasar online yang } \\
\text { memudahkan penjual secara mandiri. } \\
\text { 5. Semakin meluasnya distribusi barang } \\
\text { secara online. }\end{array}$ & $\begin{array}{l}\text { 1. Mulai banyak bermunculan produk- } \\
\text { produk olahan makanan ringan yang } \\
\text { inovatif. } \\
\text { 2. Pasar bebas, produk makanan ringan } \\
\text { impor dari luar negeri. } \\
\text { 3. Tren pasar online yang berkembang } \\
\text { pesat. }\end{array}$ \\
\hline
\end{tabular}

Hasil strategi di atas dapat diambil kesimpulan yaitu tuntutan perkembangan UKM khususnya sektor industri kecil menengah perlu adanya pengembangan produk dan perbedaan desain yang sesuai dengan permintaan pasar di era modern ini. UKM Benok 
yang mulanya menyajikan produk olahan Emping Jagung dengan menggunakan kemasan sederhana dikembangkan dengan penyajian produk dengan kemasan yang lebih mudah dalam penggunaannya. Pengembangan kemasan tersebut seperti tabel 2 di bawah ini.

Tabel 2. Pengembangan kemasan jenis stand up pouch [Sumber: Dokumentasi Penulis, 2018]

\begin{tabular}{|c|c|c|}
\hline Kemasan lama & Pengembangan & Kemasan Baru \\
\hline & $\begin{array}{c}\text { Pengembangan kemasan } \\
\text { jenis stand up pouch }\end{array}$ & \\
\hline & $\begin{array}{c}\text { Pengembangan kemasan } \\
\text { jenis stand up pouch } \\
\text { plastik PP }\end{array}$ \\
\hline
\end{tabular}

Kemasan menggunakan jenis stand up pouch adalah hasil observasi di Gerai Kemasan UKM “AA Packaging" Sido makmur 83, Jetak Asri, Dau, Mulyoagung, Malang, sehingga dengan pengembangan jenis kemasan baru yang lebih menarik dan lebih modern diharapkan memberikan kemudahan konsumen membuka dan menutup kemasan secara bertahap agar makanan ringan tetap renyah. Selain itu bertujuan untuk mereposisioning produk dengan pasar baru yang dapat meningkatkan nilai jual produk yang lebih tinggi.

\subsection{Analisis Visual (Logo)}

Kategori tanda yang dikemukakan oleh Peirce (1839-1914), bahwa logo merupakan sebuah ikon daripada suatu industri yang diwakilinya. Ikon sebagai sebuah gambar yang dihasilkan oleh manusia dapat merujuk kepada sesuatu yang diwakilinya. Ikon dapat menjadi suatu identiti pengenalan bagi objeknya, dalam hal ini bererti logo dapat menjadi identiti khas bagi industri yang diwakilinya di mana ia direka bentuk untuk mewakili visi, misi, dan identiti industri yang diinginkan.(Ibrahim et al., 2012)

Logo awal UKM Benok merupakan jenis visual brandmarks seperti tampak pada gambar 3. Logo UKM Benok kemudian oleh peneliti dilakukan analisis melalui pendekatan struktural menggunakan teori Pierce yakni ikon dan simbol. Logo UKM Benok yang terdiri dari kumpulan berbagai tanda dapat dipisahkan menjadi dua bagian yaitu uraian 
melalui visual (logo) dan uraian melalui verbal (naming). Visual logo di atas adalah jagung. Sedangkan verbal (naming) sendiri adalah nama UKM tersebut yaitu Benok.

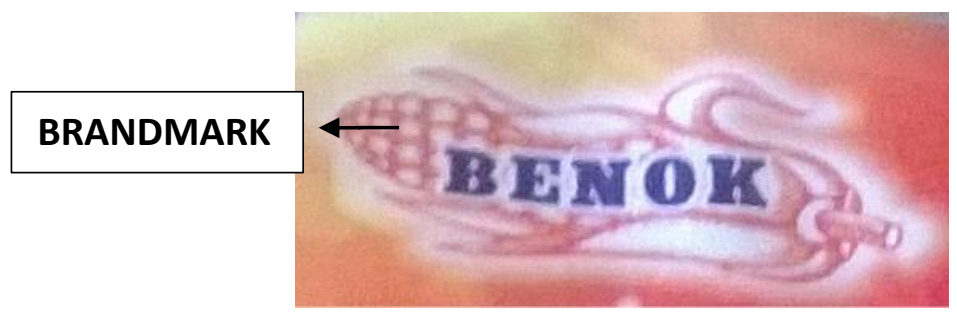

Gambar 3. Tampilan Logo UKM Benok dengan jenis visual brandmarks [Sumber: Dokumentasi Penulis, 2018]

Jika dianalisis melalui perspektif visual, logo di atas masih belum memperlihatkan ikon jagung secara jelas tentang pesan yang disampaikan. Sehingga peneliti perlu melakukan pengembangan alternatif desain logo dengan hasil seperti tabel 3 di bawah ini.

Tabel 3. Alternatif Desain Logo Benok

[Sumber: Dokumentasi Penulis, 2018]

\begin{tabular}{|c|l|l|}
\hline No & Logo Alternatif & \multicolumn{1}{|c|}{ Analisis Bentuk } \\
\hline 1 & & $\begin{array}{l}\text { Alternatif desain logo yang pertama, menggambarkan } \\
\text { bentuk jagung dengan warna kuning dan hijau sebagai } \\
\text { penguat bentuk jagung tersebut, namun karakter UKM } \\
\text { Benok sebagai makanan ringan belum terlihat jelas. Kesan } \\
\text { tampilan masih terlalu sederhana dan umum. }\end{array}$ \\
\hline 2 & $\begin{array}{l}\text { Alternatif desain kedua, menggambarkan bentuk jagung di } \\
\text { sela-sela kulitnya dengan warna kuning dan hijau sebagai } \\
\text { aksen pada bentuk jagung tersebut. Secara keseluruhan } \\
\text { bentuk ini masih belum memiliki unsur penguat identitas } \\
\text { secara visual. Bentuk jagung masih belum memiliki unsur } \\
\text { keselarasan dengan makanan ringan. }\end{array}$ \\
\hline 3 & $\begin{array}{l}\text { Alternatif desain logo ketiga, menggambarkan bentuk jagung } \\
\text { dengan paduan bentuk menyerupai wadah saji warna hijau } \\
\text { muda sebagai aksen warna kulit jagung. Secara keseluruhan } \\
\text { logo ini memiliki unsur visual seirama, kesatuan, keselarasan } \\
\text { dan keseimbangan yang cukup baik akan tetapi unsur UKM } \\
\text { Benok belum terlihat. }\end{array}$ \\
\hline 4 & $\begin{array}{l}\text { Alternatif desain logo keempat, adalah hasil pengembangan } \\
\text { dari alternatif ketiga dengan perubahan warna jagung kuning } \\
\text { matang dan kulit jagung berwarna hijau muda serta } \\
\text { penambahan motif spiral yang apabila dilihat menyerupai } \\
\text { huruf"b" dan tetap menjadi satu kesatuan dengan yang lain. } \\
\text { Sehingga unsur makanan ringan Emping Jagung UKM Benok } \\
\text { terlihat jelas. }\end{array}$ \\
\hline & \\
\hline
\end{tabular}


Desain logo yang terpilih adalah logo yang keempat, logo tersebut memiliki kesesuaian dengan filosofi yang diinginkan yakni mencerminkan hasil dari sebuah proses olahan jagung dalam bentuk makanan ringan berupa marning dan tortila. Seperti gambar 4 bentuk baru visual logo Benok di bawah ini.

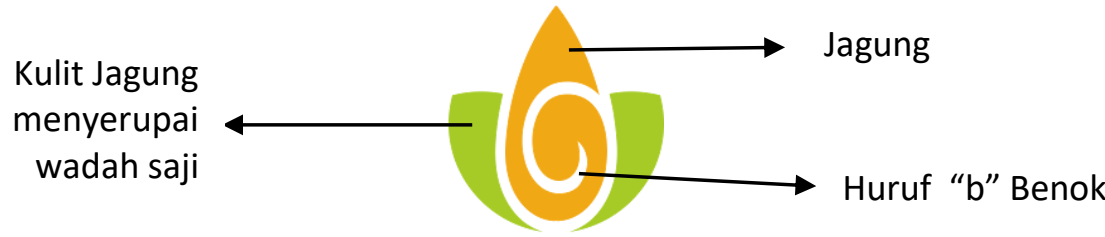

Gambar 4. Bentuk baru visual logo BENOK

[Sumber: Dokumentasi Penulis, 2018]

\subsection{Analisis Verbal (Naming)}

Logo adalah bagian dari identitas yang mudah diingat dan diucapkan, untuk itu logo juga memiliki identitas penamaan. Penamaan dalam logo Benok yang sebelumnya terdapat dalam satu kesatuan dengan visual identitasnya. Verbal pada Logo Benok masih sederhana, mulai dari pemilihan jenis font dan penempatan verbal serta penentuan warna masih belum menunjukkan identitas Benok yang diinginkan. Berikut gambar 5 di bawah ini adalah logo Benok yang sebelumnya.

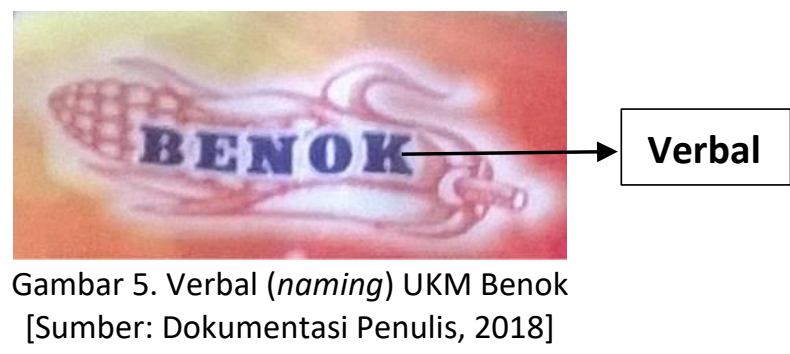

Secara verbal sebagai penguat identitas logo sangat diperlukan. Pengembangan desain verbal yang dilakukan adalah jenis font dan penempatan verbal serta penentuan warna yang sesuai dengan keinginan UKM Benok sebagai produk makanan ringan olahan jagung. Hasil pengembangan desain verbal seperti gambar 6 di bawah ini.

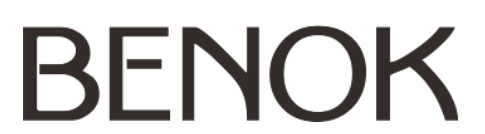

Gambar 6. Desain naming UKM Benok

[Sumber: Dokumentasi Penulis, 2018]

\subsection{Redesain Final Logo dan Verbal}

Dengan pemilihan jenis font Advertiser dan penentuan warna hitam, maka jika di gabungkan dengan visual logo telah memiliki keserasian bentuk logo seperti gambar di bawah ini. 


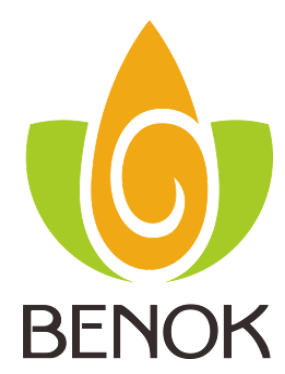

Gambar 7. Redesain logo UKM Benok

[Sumber: Dokumentasi Penulis, 2018]

Redesain logo UKM Benok pada gambar 7 di atas mempunyai kumpulan berbagai tanda yang dapat dipisahkan menjadi dua bagian yaitu :

a) Visual (logo) yang disebut brandmarks berupa inisial huruf " $b$ " yang artinya Benok dipadukan dengan bentuk jagung yang sudah matang disajikan dalam wadah makanan berwarna hijau yang memiliki makna produk makanan ringan olahan jagung berupa Emping dan Tortilla.

b) Verbal (naming) yang disebut wordmarks yaitu nama UKM Benok.

\subsection{Warna Logo UKM Benok}

Pengembangan aksen warna pada desain terpilih menggunakan warna sebagai berikut:

a) Hijau muda menggambarkan inovasi dalam pengembangan produk yang selalu fresh.

b) Hijau tua menggambarkan produk kerajinan tersebut memanfaatkan (up cycling) limbah tongkol jagung sebagai bahan bakunya.

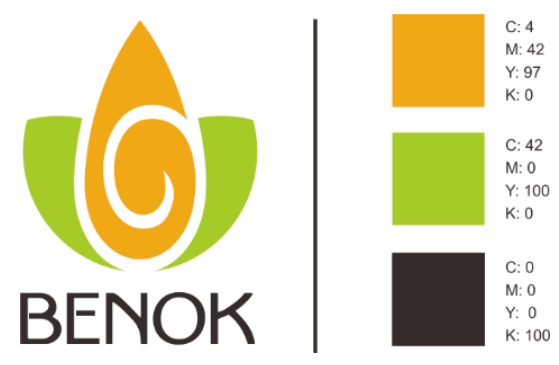

Gambar 8. Warna logo UKM Benok

[Sumber: Dokumentasi Penulis, 2018]

\subsection{Grid Logo UKM Benok}

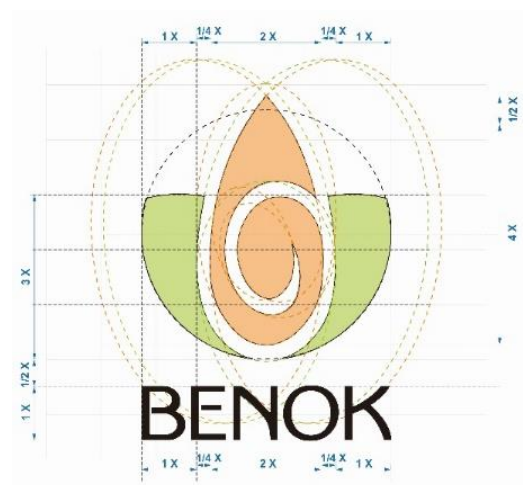

Gambar 9. Grid logo UKM Benok [Sumber: Dokumentasi Penulis, 2018] 


\subsection{Konfigurasi Logo UKM Benok}

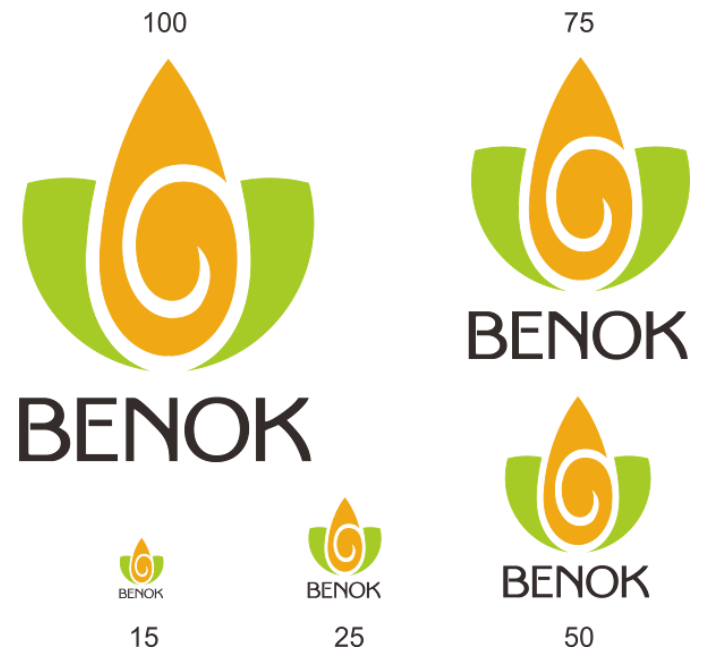

Gambar 10. Skala Logo UKM Benok

[Sumber: Dokumentasi Penulis, 2018]

Hasil konfigurasi seperti gambar 10 di atas, ukuran terbesar hingga terkecil secara visual masih jelas. Sehingga bentuk visual memiliki penciri dari merek yang akan dibangun yaitu produk makanan ringan hasil olahan jagung. Karakteristik bentuk logo dengan skala terkecil masih mudah di pahami dan dikenali oleh konsumen.

\subsection{Foto Produk sebagai Salah Satu Unsur Visual untuk Media Promosi}

Sebagai tahapan penguatan identitas dalam media promosi, maka diperlukan gambar produk makanan olahan jagung tersebut. Pengambilan gambar menggunakan cara pemotretan produk. Hasil yang didapat seperti gambar 11 di bawah ini :
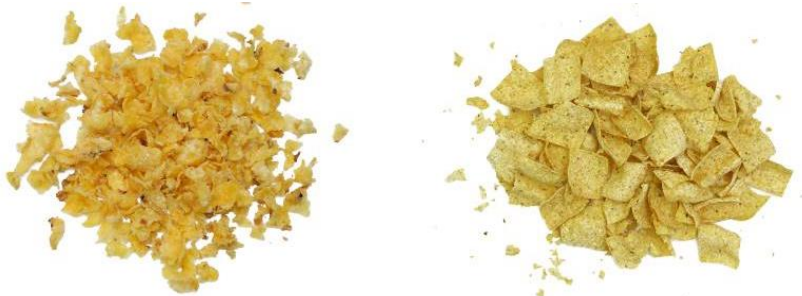

Gambar 11. Foto Produk Makanan Ringan Marning dan Tortila Jagung [Sumber: Dokumentasi Penulis, 2018]

Jika dilihat pada visualisasi hasil foto produk di atas, menunjukkan bahwa produk tersebut memiliki karakter tersendiri sebagai produk olahan jagung. Selain itu, pesan yang disampaikan adalah produk makanan ini terkesan crunchy, renyah, segar, dan fresh.

\subsection{Penerapan Desain Logo pada Label Kemasan Makanan Ringan}

Kemasan memiliki unsur-unsur visual dalam penerapannya. Penerapan logo UKM Benok pada desain kemasan seperti tabel di bawah ini. 
Tabel 4. Penerapan logo pada desain kemasan

[Sumber: Dokumentasi Penulis, 2018]

\begin{tabular}{|l|l|}
\hline Penerapan Logo pada desain kemasan & Penerapan pada kemasan stand up pouch \\
\hline & \\
\hline
\end{tabular}

\subsection{Desain Poster sebagai Media Promosi UKM}

Visualisasi desain poster gambar 12 menggunakan penambahan aksen garis hijau dengan bentuk persegi di setiap sisinya. Visual tersebut menggambarkan mengenai karakter serat kulit jagung. Sedangkan untuk warna dominan menggunakan warna kuning matang dan sedikit penambahan warna merah di produk Earning Jagung. Visual tersebut menggambarkan bahwa produk terlihat fresh, hangat dan renyah.
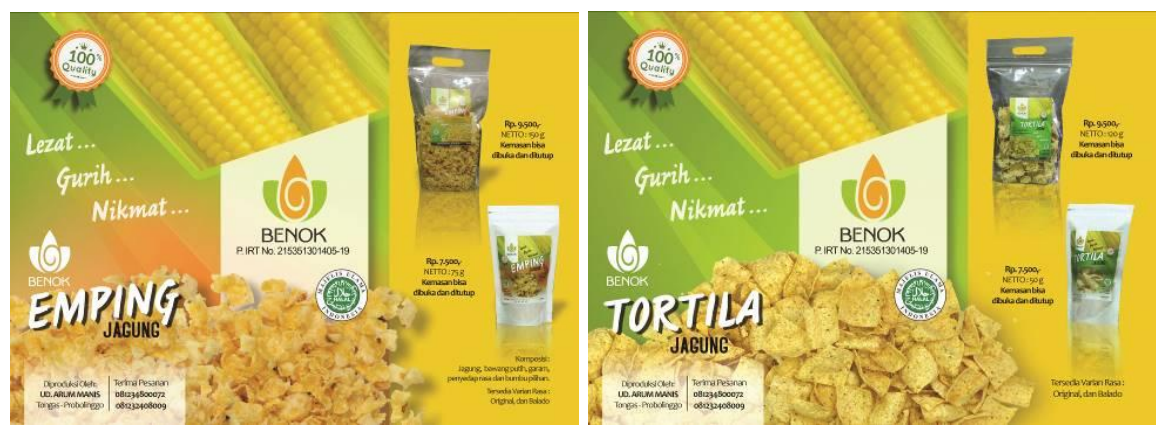

Gambar 12. Media Promosi berupa poster Marning dan Tortila UKM Benok [Sumber: Dokumentasi Penulis, 2018]

\subsection{Capaian Penerapan Desain dalam Peningkatan Daya Beli Konsumen}

Setelah menyelesaikan perancangan identitas visual dan media promosi UKM Benok dan memperkuat citra identitas produk yang berkualitas, peneliti melakukan uji terhadap 
kemasan dan identitas produk tersebut pada pasar swalayan Pusat Oleh-Oleh Khas Probolinggo di Rest Area Tongas, Probolinggo.

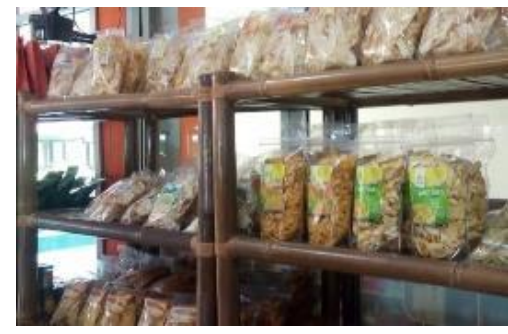

Gambar 13. Produk Emping Jagung dan Tortila Jagung UKM Benok di Pusat Oleh-Oleh di Rest Area Tongas Probolinggo

[Sumber: Dokumentasi Penulis, 2018]

Produk UKM Benok menunjukkan peningkatan dari segi kualitas yang dihasilkan. Setelah dilakukan uji pasar melalui beberapa showroom Rest Area Tongas, dalam satu minggu produk tersebut terjual rata-rata 50 buah lebih banyak dibandingkan penjualan menggunakan kemasan sebelumnya yang hanya terjual rata-rata 15 buah per minggunya.

\subsection{Citra Produk UKM}

Menjawab persoalan penelitian desain yang dihadapi oleh UKM Benok di Kabupaten Probolinggo tentang redesain logo yang sekaligus sebagai citra produk bukanlah hal yang mudah. Hal ini karena di dalam logo terutama diterapkan di dalam desain kemasan dan poster akan menggambarkan citra sebuah usaha milik UKM sekaligus upaya memmbangun brand, maka sangat wajar UKM harus memiliki strategi sendiri dalam menanamkan citra usaha dalam benak UKM. Citra merek dan keputusan pembelian sangat erat kaitannya, karena konsumen sebelum melakukan pembelian menempatkan citra merek sebagai salah satu pertimbangan dalam pengambilan keputusan pembelian. Suatu produk dengan citra yang baik diyakini konsumen dapat memenuhi kebutuhan dan keinginannya, maka dengan sendirinya akan menumbuhkan keputusan pembelian konsumen akan suatu produk yang ditawarkan. Hal tersebut sebaliknya apabila produk dengan citra merek yang kurang baik dalam pandangan konsumen, maka keputusan pembelian konsumen terhadap produk juga akan lebih rendah. Meskipun citra merek bukan satu-satunya variabel yang menentukan untuk memilih produk akan tetapi variabel citra merek cukup memberi andil yang membuat konsumen memilih dan membeli produk yang ditawarkan.(Silaningsih \& Utami, 2018)

\section{KESIMPULAN}

Upaya redesain dan Media Promosi milik Usaha Kecil Menengah (UKM) Benok dalam meningkatkan daya beli masyarakat adalah bagian dari proses mengungkap problematika yang dihadapi oleh UKM, terutama bertujuan peningkatan citra produk makanan ringan. Pembaruan pada kemasan yang sebelumnya menggunakan kemasan sederhana dengan mengganti jenis standup pouch, mampu memberikan kemudahan konsumen dan meningkatkan kualitas produk UKM Benok. Sedangkan penguatan citra produk UKM Benok dengan melakukan redesain yang meliputi : logo, brand naming, konfigurasi warna serta pendekatan unsur fotografi dalam penguatan visual dalam 
desain kemasan dan desain poster memberikan penguatan merek milik UKM Benok mampu bersaing di pasar dan siap berkompetisi. Redesain tersebut juga sekaligus menjawab upaya peningkatan citra reputasi UKM agar mudah diingat dan dikenali. Terakhir, akan mampu meningkatkan nilai jual dan daya saing dari produk serta UKM itu sendiri.

\section{DAFTAR PUSTAKA}

Ali, M. W., Waluyo, H. D., \& Listyorini, S. (2013). Pengaruh Keragaman Menu, Kualitas Produk, Citra Merek, dan Iklan Terhadap Keputusan Pembelian. Jurnal Ilmu Administrasi Bisnis, $0(0)$, Article 0.

Darmawan, R. M. A., \& Swasty, W. (2018). Perancangan Ulang Logo dan Media Promosi CV. Kinandang Putera sebagai Penguatan Identitas Visual. ANDHARUPA: Jurnal Desain Komunikasi Visual \& Multimedia, 4(02), 157-172.

Hidayat, M. J. (2011). Tinjauan Kognisi Desain Produk Kemasan Sebagai Unsur Identitas Budaya Popuer Atas Produk Kemasan Makanan Industri Kecil Menengah (IKM). Jurnal Kawistara, 1(3), Article 3.

Ibrahim, F., Nuraeni, T., Ahmad, F., Kee, C. P., \& Mustaffa, N. (2012). Bahasa Komunikasi Visual Dan Pengantaraan Produk: Satu Analisis Semiotik Bahasa Komunikasi Visual Dan Pengantaraan Produk: Satu Analisis Semiotik Bahasa Komunikasi Visual. GEMA Online ${ }^{\circledR}$ Journal of Language Studies, 12(1), Article 1.

Kementerian Koordinator Bidang Perekonomian Republik Indonesia. (n.d.). Retrieved 23 March 2020, from https://www.ekon.go.id/info-sektoral/15/13/berita-ruuciptaker-prioritaskan-umkm-bakal-permudah-munculnya-usaha-baru-hinggadorong-umkm-naik-kelas

OPUS - Creative Economy Outlook 2019. (2020). Kemenpar.Go.ld. Retrieved 13 July 2020, from https://www.kemenparekraf.go.id/post/opus-creative-economyoutlook-2019

Oscario, A. (2013). Pentingnya Peran Logo dalam Membangun Brand. Humaniora, 4(1), 191-202.

Rosandi, S. (2014). Pengaruh Citra Merek dan Desain Kemasan Terhadap Minat Beli Konsumen Pada Produk Susu Ultra (Studi pada Cafetaria Srikandi Fakultas Ekonomi Universitas Negeri Surabaya). Jurnal Pendidikan Tata Niaga (JPTN), 2(2), Article 2.

Silaningsih, E., \& Utami, P. (2018). Pengaruh Marketing Mix Terhadap Minat Beli Konsumen Pada Usaha Mikro Kecil dan Menengah (UMKM) Produk Olahan Makanan Ringan. JURNAL SOSIAL HUMANIORA, 9(2), 144-158.

Sulistya, T. A., Loka Penelitian Sapi Potong, J. P. N. 2, Anggraeny, Y. N., Loka Penelitian Sapi Potong, J. P. N. 2, Sukmasari, P. K., \& Loka Penelitian Sapi Potong, J. P. N. 2. (2018). Evaluasi Nilai Ekonomi Usaha Budi Daya Tanaman Jagung sebagai Tanaman Pakan dan Pangan di Kota Probolinggo. Prosiding Seminar Nasional Teknologi Peternakan Dan Veteriner; Semnas TPV 2017; 595-603.

Wahmuda, F., \& Hidayat, M. J. (2018). Makna Tampilan Visual Kemasan Sebagai Penerapan Redesain Kemasan Makanan Ringan UKM Benok - Kabupaten Probolinggo. Prosiding Seminar Nasional Sains dan Teknologi Terapan, 0(0), 579-584. 